\title{
Correction to: Energy efficiency trade-offs in small to large electric vehicles
}

\author{
Martin Weiss ${ }^{*}$, Kira Christina Cloos and Eckard Helmers ${ }^{*}$ []
}

\section{Correction to: Environ Sci Eur (2020) 32:46 https://doi.org/10.1186/s12302-020-00307-8}

Following publication of the original article [1], the authors would like to correct the number in the Abstract, paragraph "Results", row 5 AND on page 8 , second column.

The sentences currently read:

In Abstract: A $10 \mathrm{kWh}$ increase in battery capacity increases the mass of electric cars by $15 \mathrm{~kg}$, their drive range by $40-50 \mathrm{~km}$, and their energy consumption by $0.7-1.0 \mathrm{kWh} / 100 \mathrm{~km}$.

In Page 8: We find that each $10 \mathrm{kWh}$ of battery capacity increases vehicle mass by $15 \mathrm{~kg}$, drive range by $40-50 \mathrm{~km}$, and energy consumption by $0.7-1.0 \mathrm{kWh} / 100 \mathrm{~km}$.

The sentences should read:

In Abstract: A $10 \mathrm{kWh}$ increase in battery capacity increases the mass of electric cars by $150 \mathrm{~kg}$, their drive range by $40-50 \mathrm{~km}$, and their energy consumption by $0.7-1.0 \mathrm{kWh} / 100 \mathrm{~km}$.

In Page 8: We find that each $10 \mathrm{kWh}$ of battery capacity increases vehicle mass by $150 \mathrm{~kg}$, drive range by $40-50 \mathrm{~km}$, and energy consumption by $0.7-1.0 \mathrm{kWh} / 100 \mathrm{~km}$.

Published online: 29 May 2020
Reference

1. Weiss M, Cloos KC, Helmers E (2020) Energy efficiency trade-offs in small to large electric vehicles. Environ Sci Eur 32:46. https://doi.org/10.1186/ s12302-020-00307-8

\section{Publisher's Note}

Springer Nature remains neutral with regard to jurisdictional claims in published maps and institutional affiliations.

The original article can be found online at https://doi.org/10.1186/s1230 2-020-00307-8.

*Correspondence: weisstn@mailbox.org; e.helmers@umwelt-campus.de Environmental Planning and Technology Department, University

of Applied Sciences Trier, Environment Campus Birkenfeld, P.O. Box 1380,

55761 Birkenfeld, Germany adaptation, distribution and reproduction in any medium or format, as long as you give appropriate credit to the original author(s) and the source, provide a link to the Creative Commons licence, and indicate if changes were made. The images or other third party material in this article are included in the article's Creative Commons licence, unless indicated otherwise in a credit line to the material. If material is not included in the article's Creative Commons licence and your intended use is not permitted by statutory regulation or exceeds the permitted use, you will need to obtain permission directly from the copyright holder. To view a copy of this licence, visit http://creativeco mmons.org/licenses/by/4.0/. 